\title{
Esculetin Prevents the Induction of Matrix Metalloproteinase-1 by Hydrogen Peroxide in Skin Keratinocytes
}

\section{Ao Xuan Zhen, Mei Jing Piao, Kyoung Ah Kang, Pincha Devage Sameera Madushan Fernando, Hee Kyoung Kang, Young Sang Koh, Jin Won Hyun}

Department of Biochemistry, Jeju National University School of Medicine, Jeju, Korea

\begin{abstract}
Background: Reactive oxygen species (ROS) are involved in various cellular diseases. Excessive ROS can cause intracellular oxidative stress, resulting in a calcium imbalance and even aging. In this study, we evaluated the protective effect of esculetin on oxidative stress-induced aging in human $\mathrm{HaCaT}$ keratinocytes.

Methods: Human keratinocytes were pretreated with esculetin for 30 minutes and treated with $\mathrm{H}_{2} \mathrm{O}_{2}$. Then, the protective effects on oxidative stress-induced matrix metalloproteinase (MMP)-1 were detected by Flou-4-AM staining, reverse transcription-PCR, Western blotting, and quantitative fluorescence assay.

Results: Esculetin prevented $\mathrm{H}_{2} \mathrm{O}_{2}$-induced aging by inhibiting MMP-1 mRNA, protein, and activity levels. In addition, esculetin decreased abnormal levels of phospho-MEK1, phospho-ERK1/2, phospho-SEK1, phospho-JNK1/2, c-Fos, and phospho-c-Jun and inhibited activator protein 1 binding activity.

Conclusions: Esculetin prevented excessive levels of intracellular calcium and reduced the expression levels of aging-related proteins. (J Cancer Prev 2019;24:123-128)
\end{abstract}

Key Words: Esculetin, Reactive oxygen species, Matrix metalloproteinase-1, Aging

\section{INTRODUCTION}

Many stimuli could contribute to aging in various types of tissues, including the skin [1]. Skin cell aging, in particular, is promoted by complex mechanisms, such as mitochondrial dysfunction [2,3]. Epithelial cells are the outer most protective barrier for humans and have the ability to constantly self-regenerate [4]. Reactive oxygen species (ROS) in skin cells induce cell damage, resulting in skin disorders (e.g., cancer, aging, and inflammation) [5].

Enzymes of matrix metalloproteinase (MMP) family, especially MMP-1, play an important role in maintaining extracellular matrix, which is responsible for skin aging [6]. MMP-1 was reported to be upregulated and involved in lysis of dermal collagen [7]. $\mathrm{H}_{2} \mathrm{O}_{2}$ has been reported to induce ROS in cells, which caused oxidative stress [8]. Oxidative stress promotes skin aging by increasing MMP-1 expression levels [9]; it could activate the mitogen-activated protein kinase (MAPK) signaling pathway and the transcription factor activator protein 1 (AP-1) [10].

Plants contain numerous antioxidant compounds. Esculetin, a natural coumarin, has many bioactivities, including antioxidant, antiviral, and anticancer [11]. It is extracted from plants, including Fraxinus rhynchophylla Hance, Fraxinus chinensis Roxb, and Fraxinus aboana Lingelsh [12]. We previously found that esculetin inhibits $\mathrm{H}_{2} \mathrm{O}_{2}$-induced oxidative stress by blocking ROS generation in Chinese hamster lung fibroblasts (V79-4) [13]. Thus, it protects against $\mathrm{H}_{2} \mathrm{O}_{2}$-induced cell damage. In vivo studies have also shown that esculetin has neuroprotective, anti-anxiety, and hepatoprotective effects [14-16].

Few studies have evaluated the protective effect of esculetin

Received May 17, 2019, Revised June 14, 2019, Accepted June 14, 2019

Correspondence to: Jin Won Hyun

E-mail: jinwonh@jejunu.ac.kr, ORCID: Jin Won Hyun, https://orcid.org/0000-0002-3403-3762

Copyright (C) 2019 Korean Society of Cancer Prevention

(c) This is an Open Access article distributed under the terms of the Creative Commons Attribution Non-Commercial License (http://creativecommons.org/licenses/by-nc/4.0) which permits unrestricted non-commercial use, distribution, and reproduction in any medium, provided the original work is properly cited. 
against aging in skin cells. Therefore, we evaluated the effects of esculetin on aging induced by oxidative stress in human $\mathrm{HaCaT}$ keratinocytes.

\section{MATERIALS AND METHODS}

\section{Materials}

Esculetin (6,7-dihydroxycoumarin; Fig. 1A) was obtained from Wako Pure Chemicals (Tokyo, Japan) and was dissolved in dimethyl sulfoxide (DMSO).

\section{Cell culture conditions}

Human HaCaT keratinocytes were purchased from Cell Lines Service (Heidelberg, Germany). Keratinocytes were cultured in Dulbecco's modified Eagle's medium (Life Technologies Co., Grand Island, NY, USA) containing 10\% heat-inactivated fetal bovine serum (Life Technologies $\mathrm{Co}$.) and antibiotic-antimycotic (Life Technologies Co.) at $37^{\circ} \mathrm{C}$ in $5 \% \mathrm{CO}_{2}$.

\section{Cell viability assay}

Human HaCaT keratinocytes $\left(1.5 \times 10^{5}\right.$ cells $\left./ \mathrm{mL}\right)$ were seeded in 24 well plates and incubated for 16 hours. Subsequently, the cells were treated with esculetin $(0,1,5,10 \mu \mathrm{g} / \mathrm{mL})$ for 30 minutes and then stimulated with $\mathrm{H}_{2} \mathrm{O}_{2}(1 \mathrm{mM})$ for 24 hours. Next, MTT

A

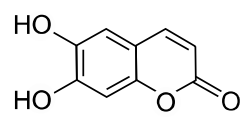

B

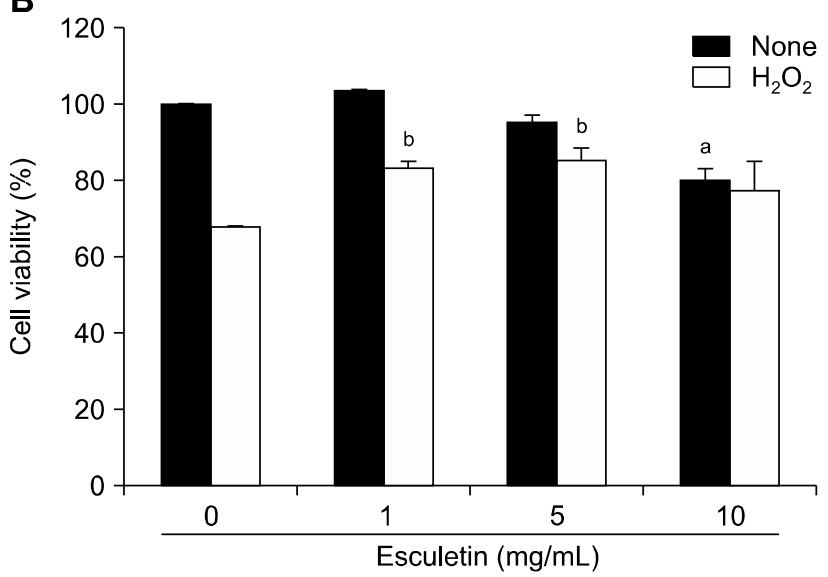

Figure 1. (A) Chemical structure of esculetin (6,7-dihydroxycoumarin). (B) Cell viability was measured using MTT assay. ${ }^{a} P<0.05$ vs. control cells, ${ }^{\mathrm{b}} P<0.05$ vs. $\mathrm{H}_{2} \mathrm{O}_{2}$-treated cells. was added into each well at $500 \mu \mathrm{g} / \mathrm{mL}$ and plates were incubated for 4 hours. Finally, the formazan crystals formed were dissolved in DMSO, and absorbance was measured by a scanning multi-well spectrophotometer at $540 \mathrm{~nm}$.

\section{Reverse transcription-PCR}

Cells $\left(1.5 \times 10^{5}\right.$ cells $\left./ \mathrm{mL}\right)$ were cultured in a $60-\mathrm{mm}$ culture dish and sequentially treated with esculetin for 30 minutes and then with $\mathrm{H}_{2} \mathrm{O}_{2}(1 \mathrm{mM})$ for 24 hours. Total RNA was isolated using the Easy-BLUE ${ }^{\mathrm{TM}}$ Total RNA Extraction Kit (iNtRON Biotechnology Inc., Seongnam, Korea). Reverse transcription reaction buffer, primers, dNTPs, and Taq DNA polymerase were used to amplify cDNA. The harvested products and $\times 6$ blue/orange loading dye were mixed. Proteins were resolved by electrophoresis on $1 \%$ agarose gels. Finally, the gels were stained with RedSafe ${ }^{\mathrm{TM}}$ Nucleic Acid Staining Solution (iNtRON Biotechnology Inc.). Images were obtained under a UV light and analyzed using Image Quant ${ }^{\mathrm{TM}} \mathrm{TL}$ analysis software (Amersham Biosciences, Uppsala, Sweden). The PCR conditions were as follows: initial denaturation at $94^{\circ} \mathrm{C}$ for 5 minutes, followed by 30 cycles at $94^{\circ} \mathrm{C}$ for 30 seconds, $55^{\circ} \mathrm{C}$ for 30 seconds, and $72^{\circ} \mathrm{C}$ for 1 minute. The primer sequences were as follows: human MMP-1 forward (5'-GGAGGAAATCTTGCTCAT-3') and reverse (5'-CTCAGAAAGAGCAGCATC-3'); human GAPDH forward (5'-TCAAGTGGGGCGATGCTGGC-3') and reverse (5-TGCC AGCCCCAGCGTCAAAG-3').

\section{Western blot analysis}

Cells were sequentially treated with esculetin and $\mathrm{H}_{2} \mathrm{O}_{2}$ as described above. Cells were harvested and lysed using a lysis buffer (120 mM NaCl, $40 \mathrm{mM}$ Tris [pH 8], and 0.1\% NP 40) on ice, and the protein concentration was detected using the Protein Assay Reagent Kit (Bio-Rad, Hercules, CA, USA). Aliquots of the protein solutions were electrophoresed on a 10\% SDS PAGE and transferred onto nitrocellulose membranes. Subsequently, the membranes were shaken with primary and secondary antibodies (Invitrogen, Carlsbad, CA, USA). Protein bands were examined using an Enhanced Chemiluminescence Western Blotting Detection Kit (Amersham, Little Chalfont, UK). The primary MMP-1 (CSB-PA07009A0Rb) antibody was purchased from Cusabio Technology (Houston, TX, USA). Primary antibodies against SAPK/ERK kinase (SEK)1 (\#9152), phospho-SEK1 (\#9156), MAPK kinase (MEK)1 (\#9124), phospho-MEK1 (\#98195), c-Jun N-terminal kinase (JNK1/2) (\#9252), phospho-JNK1/2 (\#9251), c-Fos (\#2250), and phospho-c-Jun (\#9261) were purchased from Cell Signaling Technology (Danvers, MA, USA). The primary extracellular signal-regulated kinase (ERK) 2 (sc-1647) and 
phospho-ERK1/2 (sc-7383) antibodies were purchased from Santa Cruz Biotechnology (Santa Cruz, CA, USA). The primary Actin (A2066) antibody was purchased from Sigma-Aldrich Chemical Company (St. Louis, MO, USA) [17].

\section{Matrix metalloproteinase-1 activity}

MMP-1 activity was detected by a Fluorokine ${ }^{\circledR}$ E Human Active MMP-1 Fluorescent Assay Kit (R\&D Systems Inc., Minneapolis, MN, USA) according to the manufacturer's instructions [18].

\section{Intracellular $\mathrm{Ca}^{2+}$ detection}

To measure cellular $\mathrm{Ca}^{2+}$ levels, Fluo-4-AM (Molecular Probes, Eugene, OR, USA) was used for cell staining. Cells $\left(2.0 \times 10^{5}\right.$ cells $/ \mathrm{mL}$ ) were seeded on chamber slides and sequentially treated with esculetin and/or $\mathrm{H}_{2} \mathrm{O}_{2}$. The stained cells were imaged using the FV1200 laser scanning confocal microscope (Olympus, Tokyo, Japan).

\section{Electrophoretic mobility shift assay}

Nuclear proteins were extracted from harvested cells. AP-1-binding double-stranded DNA oligomers were labeled with $\left[\gamma_{-}^{32} \mathrm{P}\right]$ ATP using T4 polynucleotide kinase. DNA-protein complexes were resolved on a $5 \%$ polyacrylamide gel, electrophoresed at $200 \mathrm{~V}$ for 2 hours, and visualized by autoradiography [19].

\section{Statistical analysis}

Differences among groups were examined by one-way ANOVA with Tukey's tests. All tests were repeated three times independently and means \pm SE were obtained. Statistical analysis was using the SigmaStat ver. 3.5 software (Systat Software Inc., San Jose, CA, USA). A value of $P \leq 0.05$ was considered statistically significant.

\section{RESULTS}

\section{Protective effect of esculetin against $\mathrm{H}_{2} \mathrm{O}_{2}$-induced cell damage}

MTT assay showed that treatment with $10 \mu \mathrm{g} / \mathrm{mL}$ esculetin induced death and damage in keratinocytes; however, treatment with 1 and $5 \mu \mathrm{g} / \mathrm{mL}$ esculetin protected cells from $\mathrm{H}_{2} \mathrm{O}_{2}$-induced toxicity ( $83 \%$ and $85 \%$, respectively). Therefore, we used the optimal concentration of esculetin $5 \mu \mathrm{g} / \mathrm{mL}$.
2. Effect of esculetin on reactive oxygen speciesinduced matrix metalloproteinase-1 expression and activation

$\mathrm{H}_{2} \mathrm{O}_{2}$-induced ROS upregulated MMP-1 at the mRNA and protein levels and esculetin inhibited this ROS-induced MMP-1 overexpression (Fig. 2A and 2B). We also found that $\mathrm{H}_{2} \mathrm{O}_{2}$ significantly induced the activation of MMP-1; pretreatment with esculetin blocked the high level of MMP-1 activation (Fig. 2C).
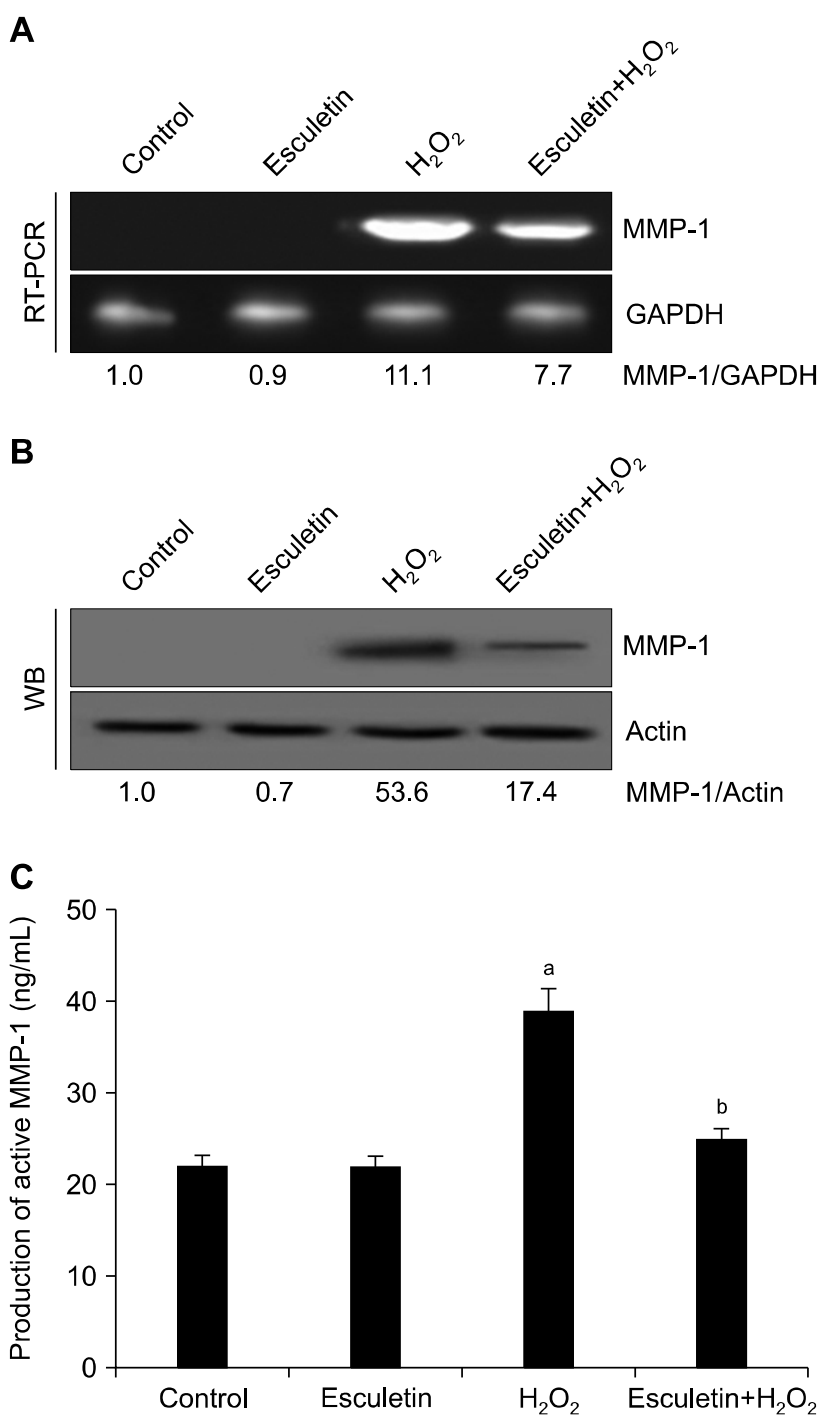

Figure 2. Effect of esculetin on $\mathrm{H}_{2} \mathrm{O}_{2}$-induced matrix metalloproteinase (MMP)-1 expression and activation. The mRNA (A) and protein levels of MMP-1 (B) were detected by reverse transcription (RT)-PCR and Western blotting (WB), respectively. Glyceraldehyde 3-phosphate dehydrogenase (GAPDH) and actin were used as loading controls. (C) MMP-1 activity was examined using a Human Active MMP-1 Fluorescent Assay Kit. ${ }^{\mathrm{a}} P<0.05$ vs. control cells, ${ }^{\mathrm{b}} P<0.05$ vs. $\mathrm{H}_{2} \mathrm{O}_{2}$-treated cells. 
A
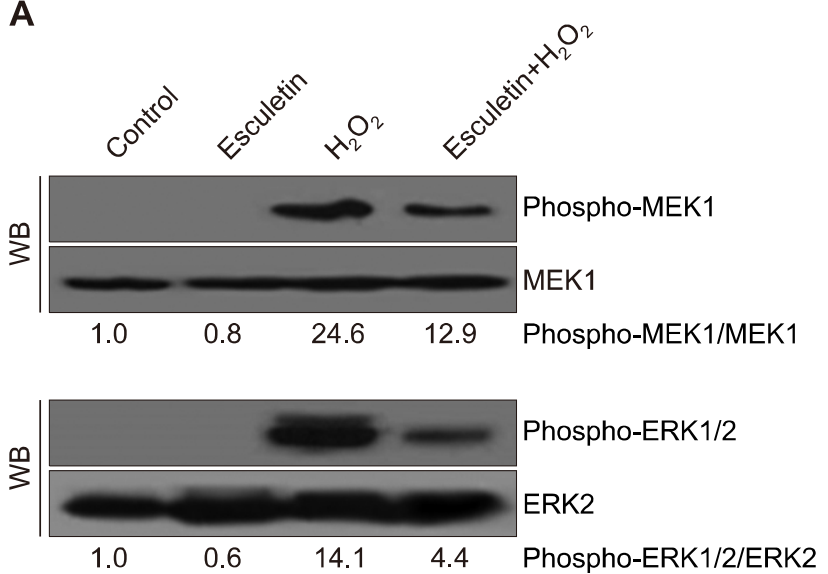

B

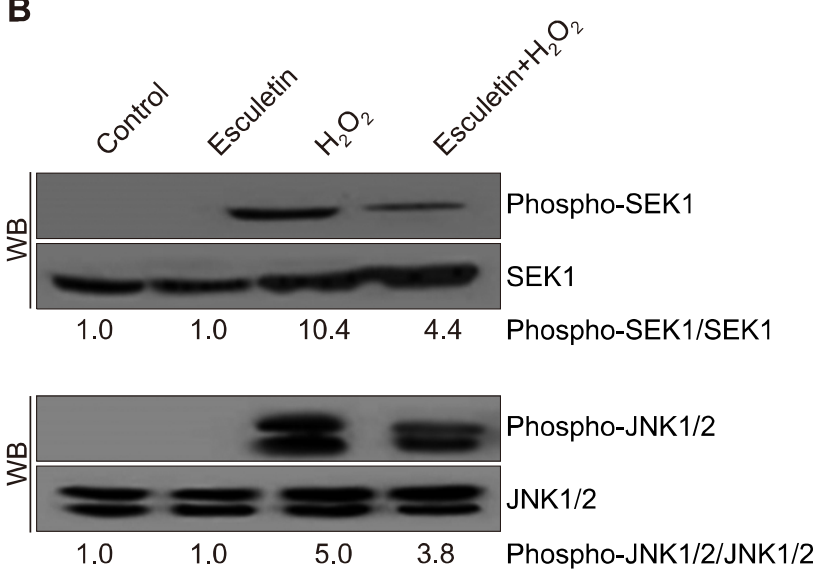

C

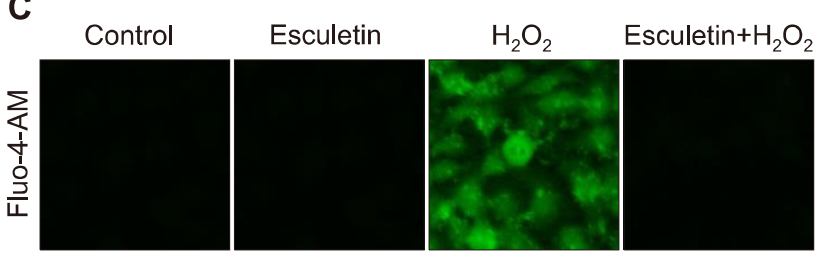

Figure 3. Effect of esculetin on $\mathrm{H}_{2} \mathrm{O}_{2}$-induced mitogen-activated protein kinases and intracellular $\mathrm{Ca}^{2+}$ levels. (A) Protein expression levels of phospho-MEK1 and phospho-ERK1/2 were detected by Western blotting (WB). (B) Expression levels of phospho-SEK1 and phospho-JNK1/2 were determined by WB. (C) Fluorescence indicating the $\mathrm{Ca}^{2+}$ level was captured by confocal microscopy using Flou-4-AM staining $(\times 100)$.

A

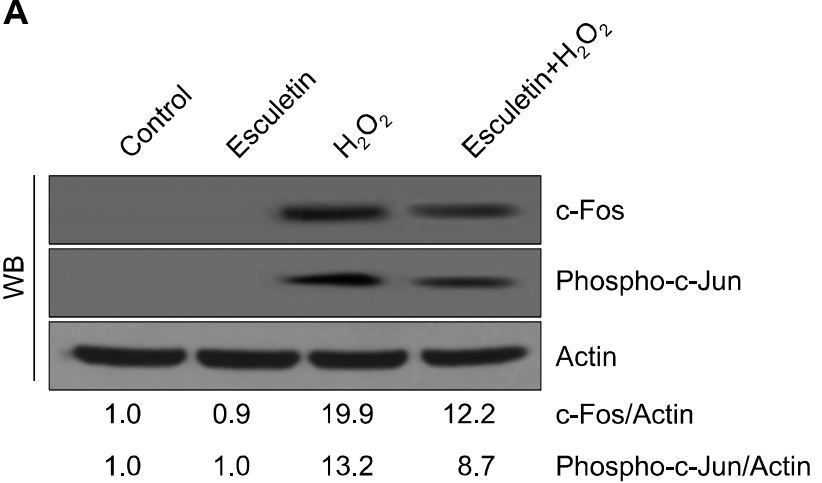

B

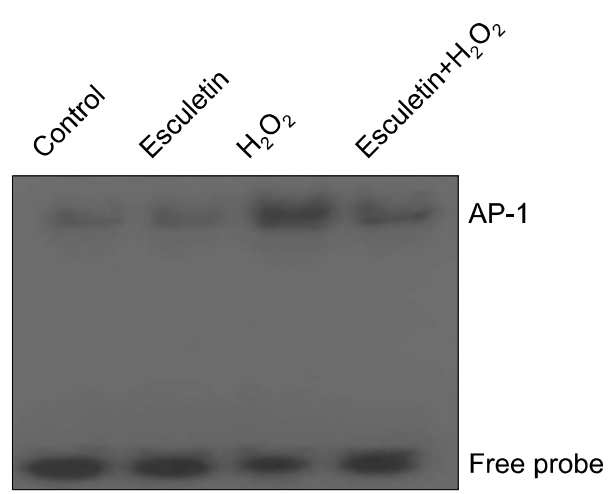

Figure 4. Effect of esculetin on $\mathrm{H}_{2} \mathrm{O}_{2}$-induced activator protein 1 (AP-1) expression. (A) Expression level of phospho-c-Jun and c-Fos determined by a Western blot (WB) analysis. Actin was used as a loading control. (B) AP-1 binding activity was assessed by electrophoretic mobility shift assay.

\section{Effect of esculetin on $\mathrm{H}_{2} \mathrm{O}_{2}$-induced mitogen-} activated protein kinases and intracellular $\mathrm{Ca}^{2+}$ accumulation

Our results showed that $\mathrm{H}_{2} \mathrm{O}_{2}$ enhanced the phosphorylation of MEK1 and ERK1/2 (Fig. 3A) and activated SEK1 and JNK1/2 (Fig. 3B). However, pretreatment with esculetin inhibited the activation of these four proteins (phospho-MEK1, phospho-ERK1/2, phospho-SEK1, and phospho-JNK1/2). A high level of intracellular
$\mathrm{Ca}^{2+}$ could activate MAPKs; thus, we evaluated intracellular $\mathrm{Ca}^{2+}$ levels [18]. We found that esculetin blocked the increase in intracellular $\mathrm{Ca}^{2+}$ levels induced by $\mathrm{H}_{2} \mathrm{O}_{2}$ (Fig. 3C).

\section{Effect of esculetin on $\mathrm{H}_{2} \mathrm{O}_{2}$-induced activator protein 1 expression}

Previous studies have shown that increase in MAPKs could regulate the heterodimerization of $\mathrm{c}-\mathrm{Jun} / \mathrm{c}-\mathrm{Fos}$ as well as the nuclear transcription factor AP-1 $[18,20,21]$. Thus, we detected 
these 3 proteins by Western blotting and found that c-Fos and phospho-c-Jun were induced by $\mathrm{H}_{2} \mathrm{O}_{2}$, and these levels were reduced by esculetin (Fig. $4 \mathrm{~A}$ ). In addition, esculetin inhibited $\mathrm{H}_{2} \mathrm{O}_{2}$-induced AP-1 binding to the promoter region (Fig. 4B).

\section{DISCUSSION}

Hydrogen peroxide $\left(\mathrm{H}_{2} \mathrm{O}_{2}\right)$, an unstable ROS, is harmful to cells, influencing cell proliferation and differentiation [22]. It can freely pass through the cell membrane, resulting in damage, such as replicative senescence [23]. Increased ROS production has the potential to impair normal skin function, causing skin aging, cancer, and inflammation. Aging resulting from ROS-induced oxidative stress, affecting macromolecules (DNA, lipid, and protein), is a complex phenomenon [24]. Therefore, a proper exogenous antioxidant agent is necessary for the reconstruction of the skin barrier. Antioxidant effect is one of the main biological activities of esculetin and is involved in its anti-inflammatory and anti-proliferative effects [12]. Furthermore, esculetin has antiphotoaging and anticancer activities [25-28]. In this study, we examined the protective effect of esculetin on ROS-induced aging.

Excessive ROS results in an increase in intracellular $\mathrm{Ca}^{2+}$, which promotes MMPs in the process of aging [29,30], and the long-term secretion of MMPs contributes to the degradation of collagen, especially MMP-1 [31]. Oxidative stress could stimulate MAPK signaling pathways, which regulate many transcription factors, including AP-1 [18]. Moreover, the binding of activated (phosphorylated) c-Jun and c-Fos to AP-1 promotes gene transcription, including $M M P-1$ transcription $[21,32]$.

Accordingly, we performed experiments to determine the effects of esculetin on ROS-induced aging. In particular, we found that the induction of MMP-1 mRNA and protein levels by ROS was reversed by esculetin. Similar results were obtained for MMP-1 activity. Furthermore, the excessive $\mathrm{Ca}^{2+}$ induced by ROS was decreased by esculetin. In addition, ROS activated the expression of MAPKs, and this activation was blocked by esculetin. Finally, transcription-related protein levels were balanced by esculetin via the inhibition of ROS.

In conclusion, esculetin shows anti-aging effects by inactivating the MAPK/AP-1 pathway. Thus, in vivo studies on anti-senescence activity of esculetin need to be carried out in the future.

\section{ACKNOWLEDGMENTS}

This work was supported by grant from the Basic Research
Laboratory Program (NRF-2017R1A4A1014512) by the National Research Foundation of Korea (NRF) grant funded by the Korea government (MSIP).

\section{CONFLICTS OF INTEREST}

No potential conflicts of interest were disclosed.

\section{REFERENCES}

1. Velarde MC, Demaria M. Targeting senescent cells: possible implications for delaying skin aging: a mini-review. Gerontology 2016;62:513-8.

2. Sharpless NE, Sherr CJ. Forging a signature of in vivo senescence. Nat Rev Cancer 2015;15:397-408.

3. Ziegler DV, Wiley CD, Velarde MC. Mitochondrial effectors of cellular senescence: beyond the free radical theory of aging. Aging Cell 2015;14:1-7.

4. Flores ER, Halder G. Stem cell proliferation in the skin: alpha-catenin takes over the hippo pathway. Sci Signal 2011:4:pe34.

5. Silva SAME, Michniak-Kohn B, Leonardi GR. An overview about oxidation in clinical practice of skin aging. An Bras Dermatol 2017:92:367-74

6. Chang C, Werb Z. The many faces of metalloproteases: cell growth, invasion, angiogenesis and metastasis. Trends Cell Biol 2001;11: S37-43.

7. Hornebeck W. Down-regulation of tissue inhibitor of matrix metalloprotease-1 (TIMP-1) in aged human skin contributes to matrix degradation and impaired cell growth and survival. Pathol Biol (Paris) 2003:51:569-73.

8. Park C, Cha HJ, Hong SH, Kim GY, Kim S, Kim HS, et al. Protective effect of phloroglucinol on oxidative stress-induced DNA damage and apoptosis through activation of the Nrf2/HO-1 signaling pathway in HaCaT human keratinocytes. Mar Drugs 2019;17:E225.

9. Leirós GJ, Kusinsky AG, Balañá ME, Hagelin K. Triolein reduces MMP-1 upregulation in dermal fibroblasts generated by ROS production in UVB-irradiated keratinocytes. J Dermatol Sci 2017;85: 124-30.

10. Pittayapruek P, Meephansan J, Prapapan O, Komine M, Ohtsuki $\mathrm{M}$. Role of matrix metalloproteinases in photoaging and photocarcinogenesis. Int J Mol Sci 2016;17:E868.

11. Chen Y, Zhang Q, Liu H, Lu C, Liang CL, Qiu F, et al. Esculetin ameliorates psoriasis-like skin disease in mice by inducing CD4+Foxp3+ regulatory T cells. Front Immunol 2018;9:2092.

12. Liang C, Ju W, Pei S, Tang Y, Xiao Y. Pharmacological activities and synthesis of esculetin and its derivatives: a mini-review. Molecules 2017;22:E387.

13. Kim SH, Kang KA, Zhang R, Piao MJ, Ko DO, Wang ZH, et al. Protective effect of esculetin against oxidative stress-induced cell damage via scavenging reactive oxygen species. Acta Pharmacol Sin 2008;29:1319-26.

14. Subramaniam SR, Ellis EM. Neuroprotective effects of umbelliferone and esculetin in a mouse model of Parkinson's disease. J Neurosci Res 2013;91:453-61.

15. Kang KA, Zhang R, Piao MJ, Lee KH, Kim BJ, Kim SY, et al. Inhibitory effects of glycitein on hydrogen peroxide induced cell 
damage by scavenging reactive oxygen species and inhibiting c-Jun N-terminal kinase. Free Radic Res 2007;41:720-9.

16. Tien YC, Liao JC, Chiu CS, Huang TH, Huang CY, Chang WT, et al. Esculetin ameliorates carbon tetrachloride-mediated hepatic apoptosis in rats. Int J Mol Sci 2011;12:4053-67.

17. Cho SJ, Kang KA, Piao MJ, Ryu YS, Fernando PDSM, Zhen AX, et al. 7,8-dihydroxyflavone protects high glucose-damaged neuronal cells against oxidative stress. Biomol Ther (Seoul) 2019;27:85-91.

18. Hyun YJ, Piao MJ, Kang KA, Zhen AX, Madushan Fernando PDS, Kang HK, et al. Effect of fermented fish oil on fine particulate matter-induced skin aging. Mar Drugs 2019;17:E61.

19. Park JY, Han X, Piao MJ, Oh MC, Fernando PM, Kang KA, et al. Hyperoside induces endogenous antioxidant system to alleviate oxidative stress. J Cancer Prev 2016;21:41-7.

20. Kim J, Kim MB, Yun JG, Hwang JK. Protective effects of standardized Siegesbeckia glabrescens extract and its active compound kirenol against UVB-induced photoaging through inhibition of MAPK/NF-KB pathways. J Microbiol Biotechnol 2017;27:242-50.

21. Kim JM, Kim SY, Noh EM, Song HK, Lee GS, Kwon KB, et al. Reversine inhibits MMP-1 and MMP-3 expressions by suppressing of ROS/MAPK/AP-1 activation in UV-stimulated human keratinocytes and dermal fibroblasts. Exp Dermatol 2018;27:298-301.

22. Gonzalez C, Sanz-Alfayate G, Agapito MT, Gomez-Niño A, Rocher A, Obeso A. Significance of ROS in oxygen sensing in cell systems with sensitivity to physiological hypoxia. Respir Physiol Neurobiol 2002;132:17-41.

23. Park WH. MAPK inhibitors, particularly the JNK inhibitor, increase cell death effects in H2O2-treated lung cancer cells via increased superoxide anion and glutathione depletion. Oncol Rep 2018;39:860-70
24. von Zglinicki T, Bürkle A, Kirkwood TB. Stress, DNA damage and ageing: an integrative approach. Exp Gerontol 2001;36:1049-62.

25. Lee BC, Lee SY, Lee HJ, Sim GS, Kim JH, Kim JH, et al. Anti-oxidative and photo-protective effects of coumarins isolated from Fraxinus chinensis. Arch Pharm Res 2007;30:1293-301.

26. Kim AD, Madduma Hewage SR, Piao MJ, Kang KA, Cho SJ, Hyun JW. Esculetin induces apoptosis in human colon cancer cells by inducing endoplasmic reticulum stress. Cell Biochem Funct 2015:33:487-94.

27. Kim AD, Han X, Piao MJ, Hewage SR, Hyun CL, Cho SJ, et al. Esculetin induces death of human colon cancer cells via the reactive oxygen species-mediated mitochondrial apoptosis pathway. Environ Toxicol Pharmacol 2015;39:982-9.

28. Lee SY, Lim TG, Chen H, Jung SK, Lee HJ, Lee MH, et al. Esculetin suppresses proliferation of human colon cancer cells by directly targeting $\beta$-catenin. Cancer Prev Res (Phila) 2013;6:1356-64.

29. Liu WH, Chang LS. Caffeine induces matrix metalloproteinase-2 (MMP-2) and MMP-9 down-regulation in human leukemia U937 cells via Ca2+/ROS-mediated suppression of ERK/c-fos pathway and activation of p38 MAPK/c-jun pathway. J Cell Physiol 2010; 224:775-85.

30. Xing YF, Xu YH, Shi MH, Lian YX. The impact of PM2.5 on the human respiratory system. J Thorac Dis 2016;8:E69-74.

31. Kang $\mathrm{CH}$, Rhie SJ, Kim YC. Antioxidant and skin anti-aging effects of marigold methanol extract. Toxicol Res 2018;34:31-9.

32. Lu J, Guo JH, Tu XL, Zhang C, Zhao M, Zhang QW, et al. Tiron inhibits UVB-induced AP-1 binding sites transcriptional activation on MMP-1 and MMP-3 promoters by MAPK signaling pathway in human dermal fibroblasts. PLoS One 2016;11:e0159998. 